\section{UČINKOVITOST NAKNADA OPĆE SOCIJALNE POMOĆI I ULOGA CENTRA ZA SOCIJALNU SKRB U BORBI PROTIV SIROMAŠTVA}

Prethodno priopćenje

Primljeno: prosinac, 2019.

Prihvaćeno: travanj, 2020.

UDK: 364.046.6-058.34

DOI 10.3935/ljsr.v27i3.350

Martina Podobnik ${ }^{1}$

orcid.org/0000-0001-7293-5794

Hrvatska komora socijalnih radnika

Antun Ilijaš ${ }^{2}$

orcid.org/0000-0002-1617-3104

Centar za socijalnu skrb Zagreb; Hrvatska komora socijalnih radnika borbi protiv siromaštva i borbi za ljudska prava. Centri za socijalnu skrb predstavljaju ključnu instituciju u tom području, a specifično važnu ulogu nose odjeli novčanih naknada u kojima socijalnih radnici svakodnevno rade s najsiromašnijim članovima društva. U Hrvatskoj sustav novčanih naknada čine programi opće i kategorijalne pomoći. Ovaj rad posvećen je programima opće pomoći, zajamčenoj minimalnoj naknadi i jednokratnoj naknadi. Navedena prava uređena su Zakonom o socijalnoj skrbi koji je od 2011. godine prošao šest izmjena i time donosio novine i u području ostvarivanja naknada opće socijalne pomoći. $U$ radu su prikazane najvažnije promjene te osvrt na njihovu praktičnu primjenjivost. Dane su i smjernice za unaprjeđenje učinkovitosti dviju najvažnijih novčanih naknada i to u pogledu visine naknada i njihove ciljanosti, učinkovitosti u pogledu korisničkih skupina djece i umirovljenika i radne aktivacije mladih (i) radno sposobnih korisnika novčanih naknada. Sobzirom na ključnu ulogu socijalnih rad-
Ključne riječi:

zajamčena minimalna

naknada, siromaštvo, socijalni rad, centar za socijalnu skrb. 
nika u rješavanju priznavanju prava na novčane naknade, poseban prostor posvećen je kritičkom osvrtu na ulogu socijalnih radnika u odjelu novčanih naknada.

\section{UVOD}

Fenomenom siromaštva bavi se široka društvena, stručna i znanstvena javnost. Od početka svjetske krize (2008.-2009.) na razini Europske unije ${ }^{3}$ uočljivo je povećanje broja ljudi koji žive u riziku od siromaštva i socijalne isključenosti (EMIN, 2017.). Tako se 2012 . godine govorilo o stopi od $24,7 \%$ populacije EU-a (123 milijuna ljudi) što je, prema podacima Europske mreže za minimalni dohodak ${ }^{4}$ (eng. European Minimal Income Network) (2017.), predstavljalo porast od 6,4 milijuna ljudi u odnosu na 2008. godinu. Prva smanjenja zabilježena su 2015. godine kada se stopa smanjila na $23,7 \%$ (118,8 milijuna ljudi) što u odnosu na 2008. i dalje predstavlja povećanje od 1,2 milijuna ljudi umjesto ciljanog smanjenja od 20 milijuna postavljenog Strategijom Europa 2020 (2010.). Pozitivni pomaci se i dalje bilježe pa prema Anketi o dohotku stanovništva 2017. (DZS, 2018.) navodi da je u zemljama EU-28 u 2017. godini 16,9\% populacije živjelo u riziku od siromaštva, a u Hrvatskoj 20,0\% populacije, odnosno 2018. godine $19,3 \%{ }^{5}$ (DZS, 2019.). Rezultati istraživanja Knežević, Marić i Šućur (2017.: 163) pokazuju kako se »između $10 \%$ i $15 \%$ hrvatskih građana suočava s ozbiljnim izazovima siromaštva koji podrazumijevaju nemogućnost podmirivanja osnovnih potreba dok se daljnjih 5-10\% građana nalazi na granici siromaštva«. Prema podacima Državnog zavoda za statistiku ${ }^{6}$ (2019.), u 2018. godini je čak 24,8\% stanovništva živjelo u riziku od siromaštva ili socijalne isključenosti. $U$ teškoj materijalnoj deprivaciji je u 2018. godini 8,6\% stanovništva (DZS, 2019.).

Uz fenomen siromaštva usko se vežu sustavi socijalne pomoći. U Hrvatskoj je pravo na socijalnu pomoć uređeno dvama temeljnim pravnim aktima: Ustavom i Zakonom o socijalnoj skrbi.

Sustav socijalne pomoći Hrvatske sačinjava veći broj različitih prava namijenjenih najugroženijim skupinama stanovništva. Građani mogu ostvariti socijalnu pomoć u novčanom ili naturalnom obliku, ali i kao usluge. Novčane pomoći obično dijelimo na naknade opće socijalne pomoći te kategorijalne. Kategorijalne su namijenjene specifičnim skupinama ili za zadovoljavanje određenih potreba, a opća socijalna pomoć namijenjena je osobama koje nisu u stanju zadovoljiti osnovne životne po-

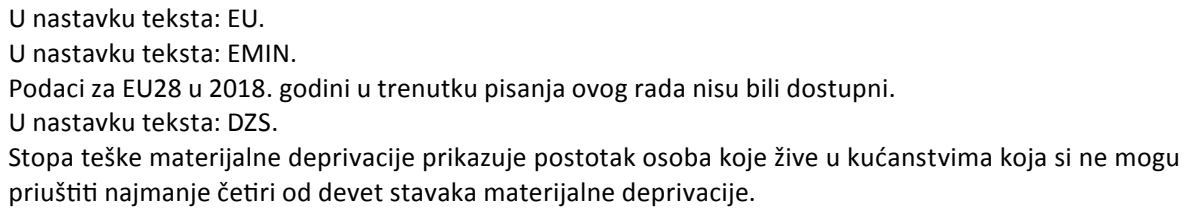


trebe. Primjeri kategorijalnih naknada u Hrvatskoj su osobna invalidnina, doplatak za pomoć i njegu, naknada do zaposlenja te status roditelja njegovatelja ili status njegovatelja (Zakon o socijalnoj skrbi, 2013., 2014., 2015., 2016., 2017.a i 2017.b). U naknade opće socijalne pomoći u Hrvatskoj ubrajamo zajamčenu minimalnu naknadu te jednokratnu naknadu.

U Hrvatskoj je program stalne opće socijalne pomoći uveden 1998. godine pod nazivom stalna pomoć. Do danas je naknada nekoliko puta mijenjala naziv pa su, osim prvotnog, korišteni i naziv pomoć za uzdržavanje (od 2011. do 2014. godine) te zajamčena minimalna naknada ${ }^{8}$ (od 2014. godine). Ona predstavlja najbolje ciljani program usmjeren na najsiromašnije građane (Svjetska banka, 2007., prema Babić, 2008.), a financira se iz državnog proračuna. U većini država EU programi poput ZMN-a financiraju se sa središnje (državne) razine. U nekim drugim državama, poput Austrije, Belgije, Danske, njihovo financiranje je podijeljena odgovornost između državne i lokalne razine, dok je u nekoliko država financiranje isključiva odgovornost lokalne ili regionalne vlast (Finska, Latvija, Švedska) (EMIN, 2017.). Važnost ZMN-a ogleda se i u činjenici kako ga u Hrvatskoj koristi približno 1,8\% stanovništva (MDOMSP ${ }^{9}, 2019$.). Drugi program opće socijalne pomoći jest jednokratna naknada koju prema podacima za 2018. godinu koristi 1,66\% (MDOMSP, 2019.). Valja naglasiti kako se neke druge naknade iz sustava socijalne skrbi vezuju uz ZMN. U tom kontekstu, važno je istaknuti naknadu za ugroženog kupca energenata koja ima sve veću važnost sudeći prema broj korisnika10 i to u 2015. godini 64566 prava (MDOMSP, 2016.), 2016. godini = 61 043 prava (MDOMSP, 2017.) 2017. godini = 59888 (MDOMSP, 2018.) te 2018. godini $=60443$ (MDOMSP, 2019.).

Centri za socijalnu skrb ${ }^{11}$ ključna su ustanova s javnim ovlastima u kontekstu naknada opće socijalne pomoći. Od 2011. godine primjenjuju organizaciju rada po modelu »ured sve na jednom mjestu« unutar koje je oformljen i odjel za novčane naknade. Socijalni radnici tog odjela svakodnevno rade s korisnicima koji žive u siromaštvu, a zadaća im je, osim prvostupanjskog rješavanja o naknadama, pružanje usluga socijalnog i drugog stručnog rada, poticanje na razvijanje samopomoći, pomoć u suzbijanju socijalnih i osobnih problema te uključivanju korisnika u zajednicu. Oni posjeduju specifično iskustvo i perspektivu rada s osobama koje žive u siromaštvu.

8 U nastavku teksta: ZMN.

9 Ministarstvo za demografiju, obitelj, mlade i socijalnu politiku. Kratica će biti korištena u nastavku teksta.

10 Tema energetskog siromaštva u Hrvatskoj je nedovoljno istražena unatoč vrlo izraženoj problematici među stanovništvom Republike Hrvatske. Stoga upućujemo preporuku praktičarima i znanstvenicima da u budućnosti posebnu pažnju usmjere istraživanju tog fenomena te snažnije progovaraju i izvještavaju o svojim nalazima i razmišljanjima o mogućnostima ublažavanja problematike energetskog siromaštva.

11 U nastavku teksta: CZSS. 
Kao takvi, predstavljaju most između politika i praktičnog djelovanja (Ajduković, Matančević i Rimac, 2018.). Najžešće rasprave u tim profesionalnim krugovima vode se upravo o pitanjima smislenosti i učinkovitosti ZMN-a te jednokratne naknade u Hrvatskoj, a kojima će posebna pozornost biti posvećena u ovom radu.

U prvom dijelu rada bit će prikazan pregled najvažnijih zakonodavnih odredbi kojima je uređeno ostvarivanje prava na ZMN i jednokratnu naknadu u Republici Hrvatskoj. Kritičkom osvrtu s prijedlozima za unaprjeđenje zakonodavnih rješenja i međusektorske suradnje u pogledu ostvarivanja prava na ZMN i jednokratnu naknadu posvećen je drugi dio rada. S obzirom na veliki značaj profesije socijalnog rada te odjela novčanih naknada CZSS-a u borbi protiv siromaštva posljednji dio rada donosi osvrt na njihove uloge i mogućnosti u radu s najsiromašnijim građanima.

\section{ZAKONODAVNO UREĐENJE PRAVA NA ZAJAMČENU MINIMALNU NAKNADU I JEDNOKRATNU NAKNADU}

1998. godine u Hrvatskoj je prvi put uveden program stalne novčane pomoći usmjeren na najsiromašnije stanovništvo pod nazivom stalna pomoć. Kao što je ranije istaknuto, pravo je nekoliko puta mijenjalo svoj naziv od početnog stalna pomoć, pomoć za uzdržavanje do konačnog ZMN-a. Iznos naknade se prema Zakonu o socijalnoj skrbi utvrđuje sukladno osnovici koju svake godine odlukom propisuje Vlada Republike Hrvatske. Za izračunavanje visine osnovice koriste se statistike Eurostatove službene metodologije za praćenje siromaštva prema kojoj se siromašnima smatraju osobe čiji ekvivalentni dohoci jesu manji od $60 \%$ medijana nacionalnog dohotka, odnosno od granice relativne linije siromaštva (Šućur, 2012.).

Iznos osnovice se od trenutka uvođenja programa stalne pomoći rijetko mijenjao. Od 1998. do 2001. godine iznos osnovice bio je 350 kuna (Odluka o osnovici za ostvarivanje prava po osnovi socijalne skrbi, 1998., čl. 1) nakon čega se 2001. godine povisuje na 400 kuna (Odluka o osnovici za ostvarivanje prava po osnovi socijalne skrbi, 2001., čl.1.), da bi od 1.11.2008. godine dosegao 500 kuna (Odluka o osnovici za ostvarivanje prava po osnovi socijalne skrbi, 2008., čl. 1.). Od 2014. godine pa do danas osnovica iznosi 800 kuna. Takvo povećanje bilo je već prijeko potrebno s obzirom na porast troškova života, posebno ako uzmemo u obzir i činjenicu kako je 2012. godine u Hrvatskoj stopa PDV-a porasla s ionako visokih $23 \%$ na $25 \%$ što je uzrokovalo dodatni porast cijena roba i usluga.

lako je u pogledu uređivanja ostvarivanja prava na stalnu pomoć u sustavu socijalne skrbi Zakon o socijalnoj skrbi ključan i kao takav bi trebao biti stabilna okosnica sustava, on je od 2011. godine prošao kroz šest izmjena i dopuna koje su unijele određene nesigurnosti u postupanja CZSS-a (Ilijaš i Podobnik, 2018.), ali i dovele do 
zbunjenosti nekih korisnika. Osim naziva te visine osnovice, mijenjani su i kriteriji za ostvarivanje prava kao i postoci za izračunavanje iznosa naknada.

Sukladno važećem Zakonu o socijalnoj skrbi (2013., .2014., 2015., 2016, 2017.a, 2017.b, čl. 28.), pravo na ZMN priznaje se samcu ili kućanstvu koji nemaju sredstava za uzdržavanje niti ih je u mogućnosti ostvariti radom, primitkom od imovine, kao ni od obveznika uzdržavanja. Samac ili kućanstvo nemaju pravo na ZMN ako imaju u vlasništvu drugi stan ili kuću koju ne koriste za stanovanje, odnosno poslovni prostor koji ne koriste za obavljanje registrirane djelatnosti te vrijedne pokretnine, a koje mogu prodati ili iznajmiti te na taj način osigurati sredstva za podmirenje osnovnih životnih potreba. Nadalje, samac ili kućanstvo nemaju pravo na ZMN i u slučaju da su vlasnici osobnog automobila, osim ako vozilo služi za prijevoz osobe s invaliditetom, starije, nemoćne osobe ili je prema procjeni stručnog radnika CZSS-a vozilo nužno zbog prometne izoliranosti (Zakon o socijalnoj skrbi, 2013., 2014., 2015., 2016., 2017.a, 2017.b, čl. 29., st. 1.). Jednako tako, pravo na ZMN ne može se priznati ako samac ili kućanstvo koriste vozilo u vlasništvu druge pravne ili fizičke osobe, ako su sklopili ugovor o doživotnom i/ili dosmrtnom uzdržavanju kao primatelj uzdržavanja, ako radno sposobni samac nije evidentiran u zavodu za zapošljavanje kao nezaposlena osoba ili ako uzdržavanje mogu osigurati po drugoj osnovi (Zakon o socijalnoj skrbi, 2013., 2014., 2015., 2016., 2017., 2017.a, 2017.b, čl. 29., st. 1.).

Način na koji se iznos ZMN-a izračunavao mijenjao se nekoliko puta u nastojanjima da se većim iznosima obuhvate one najranjivije skupine stanovništva (primjerice, samohrani roditelji). U Tablici 1. prikazane su zakonske izmjene u posljednjih 10 godina.

Zakonom koji je bio na snazi tijekom 2009. godine bili su propisani različiti postoci za izračunavanje visine naknade za djecu ovisno o dobi (vidi Tablicu 1.) čime se željelo u što većoj mjeri iznose prilagoditi razvojnim potrebama djece i rastućim troškovima obitelji u tijeku odrastanja djece. Ono što je, također, vidljivo iz tablice jest i činjenica da je takvo stupnjevanje postotka naknade ovisno o dobi ukinuto stupanjem na snagu Zakona u 2014. godini te do danas nije vraćeno u zakonske odredbe. Osnovica za dijete, bez obzira na njegovu dob, iznosi 40\%, odnosno 320 kuna mjesečno. Prema Kletečki-Radović, Vejmelka i Družić Ljubotina (2017.), važeći Zakon o socijalnoj skrbi (2013., 2014., 2015., 2016., 2017.) tako ne prihvaća rizike života u siromaštvu za razvoj djeteta što je u direktnom nesuglasju s prioritetnim ciljevima i definiranim ranjivim skupinama djece u »Nacionalnoj strategiji za prava djece od 2014. do 2020. godine«. Sukladno tome, nije niti usmjeren na ublažavanje učinaka siromaštva i podršku za prevladavanje nepovoljnih okolnosti u kojima žive siromašna djeca (Kletečki-Radović, Vejmelka i Družić Ljubotina, 2017.). Vidljiva iznimka je prepoznavanje rizika samohranog roditeljstva pa je u tom smislu određen iznos od 440 kuna za dijete samohranog roditelja (vidi Tablicu 1.). 
Tablica 1. Zakonske promjene iznosa stalne novčane naknade u Hrvatskoj

\begin{tabular}{|c|c|c|c|c|c|c|c|c|}
\hline & \multicolumn{2}{|c|}{$\begin{array}{l}2009 .^{12} \\
\text { Osnovica = } \\
500 \text { kuna }\end{array}$} & \multicolumn{2}{|c|}{$\begin{array}{l}2011 . \\
\text { Osnovica = } \\
500 \text { kuna }\end{array}$} & \multicolumn{2}{|c|}{$\begin{array}{l}2014 . \\
\text { Osnovica = } \\
800 \text { kuna }\end{array}$} & \multicolumn{2}{|c|}{$\begin{array}{l}2015 . \\
\text { Osnovica = } \\
800 \text { kuna }\end{array}$} \\
\hline & $\%$ & $\begin{array}{c}\text { Iznos } \\
\text { (kn) }\end{array}$ & $\%$ & $\begin{array}{l}\text { Iznos } \\
\text { (kn) }\end{array}$ & $\%$ & $\begin{array}{l}\text { Iznos } \\
\text { (kn) }\end{array}$ & $\%$ & $\begin{array}{c}\text { Iznos } \\
\text { (kn) }\end{array}$ \\
\hline Samac & 100 & 500 & 120 & 600 & 100 & 800 & & \\
\hline Radno nesposobni & & & & & & & 120 & 920 \\
\hline Radno sposobni & & & & & & & 100 & 800 \\
\hline Odrasla osoba - član obitelji & 80 & 400 & 80 & 400 & 60 & 480 & 60 & 480 \\
\hline Dijete do 7. godine & 80 & 400 & 80 & 400 & 40 & 320 & 40 & 320 \\
\hline Dijete od 7. do 15 . godine & 90 & 450 & 90 & 450 & 40 & 320 & 40 & 320 \\
\hline $\begin{array}{l}\text { Dijete od } 15 . \text { do } 18 \text {. godine, ali } \\
\text { najduže do } 26 \text {. godine }\end{array}$ & 100 & 500 & 100 & 500 & 40 & 320 & 40 & 320 \\
\hline $\begin{array}{l}\text { Potpuno radno nesposobna } \\
\text { osoba koja živi sama }\end{array}$ & +50 & 750 & +50 & 750 & & & & \\
\hline $\begin{array}{l}\text { Potpuno radno nesposobna } \\
\text { osoba koja živi u obitelji }\end{array}$ & +30 & 650 & +30 & 650 & & & & \\
\hline $\begin{array}{l}\text { Trudnica nakon } 12 \text { tjedana } \\
\text { trudnoće i rodilja do } 2 \text { mjeseca } \\
\text { nakon poroda }\end{array}$ & +50 & 750 & +50 & 750 & & & & \\
\hline Dijete samohranog roditelja & +25 & 625 & +25 & 625 & & & 55 & 440 \\
\hline Samohrani roditelji & & & & & 100 & 800 & 100 & 800 \\
\hline
\end{tabular}

Utjecaj uklanjanja odredbi razlikovanja visine naknade ovisno o dobi djeteta najbolje se može dočarati primjerom. Pa tako, ukoliko za primjer uzmemo obitelj s dvije odrasle osobe i dvoje djece, utvrdit ćemo kako prema zakonu važećem od 2014. godine pa do danas mogu ostvariti iznos ZMN-a u visini od 1560 kuna, a prema ranije važećem zakonu ista obitelj mogla je ostvariti iznos od 1600 kuna do 1800 kuna ovisno o starosti djeteta uz uvjet ispunjavanja drugih zakonom propisanih uvjeta. $\mathrm{U}$ neformalnim raspravama među socijalnim radnicima često se ističe potreba za vraćanjem odredbi koje će uvažavati razvojne potrebe djece. Potonje posebno iz razloga što se u nepovoljni položaj dovelo obitelji s većim brojem djece. Do izražaja posljedično dolazi problem siromaštva posebno ugrožene skupine: djece čiji položaj ovisi o ekonomskim prilikama roditelja (Banjedvorec, 2014.). Koliko je važno uvažiti razvojne potrebe djece, pokazuju i istraživanja. Sustavan pregled svih objavljenih

12 Zakon o socijalnoj skrbi (1997., 2001., 2001., 2001., 2003., 2006., 2007., 2010., čl. 16., st.3.). 
radova od 1998. do 2012. te od 2012. do 2017. (Cooper i Stewart, 2013., 2017., prema Rubil, Stubbs i Zrinščak, 2018.), a koji su nedvojbeno utvrdili uzročno-posljedičnu vezu, pokazao je da postoje jaki dokazi da je odrastanje u siromaštvu značajno povezano s lošijim ishodima, i to u kognitivnom razvoju, školskom uspjehu, zdravlju te općenito u socijalizacijskim ishodima. Povezanost se pokazala većom kod kućanstava s najnižim dohocima što je dovelo do zaključka da upravo kod takvih osoba smanjenje dohodovnog siromaštva ima važne i mjerljive učinke na razvoj djece te njihov osobni uspjeh i društvenu afirmaciju (Rubil, Stubbs i Zrinščak, 2018.). Družić Ljubotina, Sabolić i Kletečki Radović (2017.) utvrdili su kako su djeca iz siromašnih obitelji pozitivno orijentirana prema školi, međutim suočavaju se s problemima u pristupu informacijama i obrazovanju. Djeca iz siromašnih obitelji češće pohađaju trogodišnje srednjoškolske programe jer ih mogu brže završiti, (nerijetko) pohađati plaćenu praksu i tako financijski pomoći svojim roditeljima (Kletečki Radović, Vejmelka i Družić Ljubotina, 2017.). Posljedice odrastanja u siromaštvu mogu biti i ozbiljnije ukoliko dijete živi u ekstremnom siromaštvu ili je riječ o dugotrajnom siromaštvu ili siromaštvu u ranom djetinjstvu (Šućur i sur., 2015.). Zbog svega navedenog, važno je uvažiti različitost razvojnih potreba djece prilikom određivanja visine iznosa naknade te na političkim i/ili zakonodavnim razinama usvojiti ideju ulaganja u djecu i omogućavanja jednakih prilika kao dugotrajnog socijalnog ulaganja te razbijanja međugeneracijskog prijenosa siromaštva.

Nadalje, novinu u Zakonu iz 2014. godine predstavljala je odredba prema kojoj naknada ne smije prelaziti iznos bruto minimalne plać $e^{13}$ u Republici Hrvatskoj bez obzira što bi prema standardnom izračunu naknada trebala biti veća (Zakon o socijalnoj skrbi, 2013., čl. 30., st. 4.) čime se u većoj mjeri počelo provoditi i poštovati načelo socijalne pravičnosti (Zakon o socijalnoj skrbi, 2013., čl. 8.). Međutim, Banjedvorec (2014.) ističe kako se tim zakonskim novinama dovelo u nepovoljni položaj i dobrobit obitelji od sedmero i više djece s obzirom da su takve obitelji prema ranijem zakonu mogle ostvariti iznos od 3200 kuna, a prema novom zakonu u 2014. godini su najviše mogli ostvariti 3017 kunu (vidi Tablicu 2.). Prema popisu stanovništva iz 2011. godine, u Hrvatskoj je živjelo 1078 obitelji sa sedmero i više djece ${ }^{14}$.

Kao što je vidljivo iz Tablice 2., s porastom bruto minimalne plaće se i smanjuje krug obitelji koje su pogođene odredbama koje štite načelo socijalne pravičnosti (primjerice, u 2019. godini tek obitelji s 9, 10 djece i više). MDOMSP (2019.) u godišnjem izvješću za 2018. godinu iznosi podatak kako je obitelji sa 7 i više djece među korisnicima ZMN-a bilo 335 pri čemu se ne prikazuju podaci o broju obitelji s 9, 10 i

13 U 2014. godini iznos bruto minimalne plaće u Republici Hrvatskoj je iznosi 3 017,61 kuna (Uredba o visini minimalne plaće, 2013., čl. 1.).

14 Prema popisu stanovništva iz 2011. godine, u Hrvatskoj je živjelo 585 obitelji sa sedmero djece, 277 obitelji sa osmero djece, 118 obitelji s devetero djece te 98 obitelji sa desetero i više djece. 


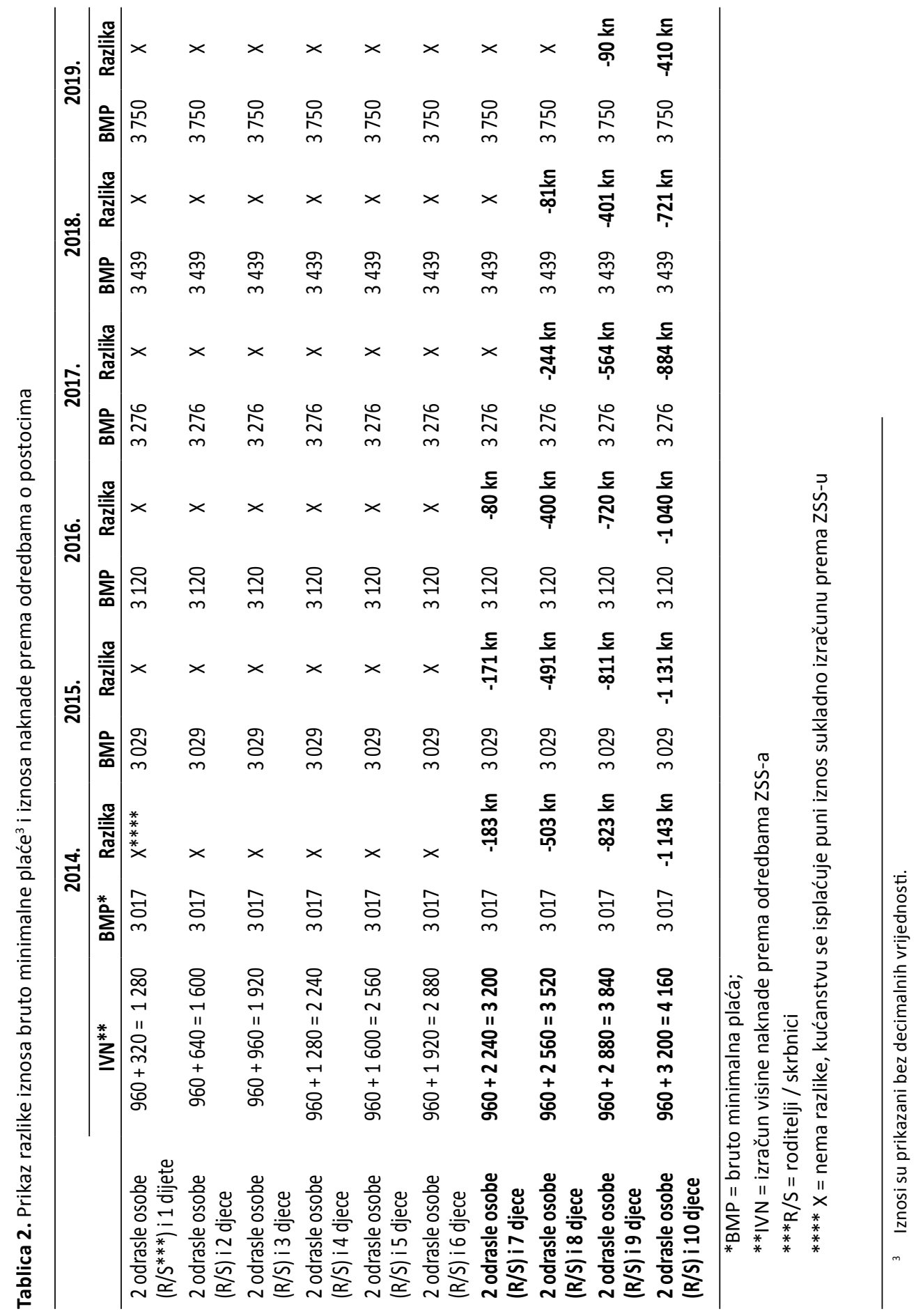


više djece. S druge strane, u praksi su se stručnjaci susretali sa slučajevima namjernog isključivanja djece iz obrazovnog sustava radi ostvarivanja većih iznosa naknade pa ovu odluku zakonodavca valja sagledati i sa strane sprječavanja zlouporaba i smanjenja slučajeva ograničavanja prava djece na obrazovanje.

Određene zakonske promjene u pogledu ZMN-a prouzrokovale su gorljive rasprave u profesionalnim krugovima. Primjerice, člankom 39. Zakona o socijalnoj skrbi (2013.) bilo je propisano vremensko ograničenje razdoblja primanja naknade na rok od 2 godine za radno sposobne korisnike. Praksa je bila podijeljena po pitanju te odredbe koja je naposljetku ocijenjena negativnom pa i od strane Europskog parlamenta (2017.) definirana kao nepovoljna za osobe u riziku od siromaštva. Takva odredba u sljedećim izmjenama Zakona je izbačena te zamijenjena za korisnike povoljnijim zakonskim rješenjima. Zakon od tada pa sve do danas propisuje da u slučaju da se radno sposobna osoba koja je korisnik naknade najmanje godinu dana zaposli, naknada joj se prvi mjesec ne ukida, drugi mjesec smanjuje se za $25 \%$, a treći za $50 \%$, da bi se nakon trećeg mjeseca u potpunosti ukinula ako prosječni prihod $u$ ta tri mjeseca prelazi visinu priznatog iznosa naknade (Zakon o socijalnoj skrbi, 2013., čl. 40.) ${ }^{15}$. Banjedvorec (2014.) navodi kako je pitanje što nakon prekida zaposlenja s obzirom da se gleda prosjek zadnja tri mjeseca, što znači da odmah sljedećeg mjeseca po isteku zaposlenja osoba najvjerojatnije ne može ostvariti pravo na ZMN. Primjer su i sezonski turistički radnici. Oni zasigurno, po završetku sezonskog rada, narednih dva, tri mjeseca, ovisno o visini prihoda, neće ispunjavati uvjete za ostvarivanje prava na ZMN, a upravo zbog prosjeka prihoda za vrijeme sezonskog rada. Ukoliko takva osoba živi u samačkom kućanstvu, može ostvariti pravo na ZMN u visini od 800 kuna te njeni prosječni prihodi u prethodna 3 mjeseca od datuma podnošenja zahtjeva za priznavanjem ZMN-a ne smiju prelaziti taj iznos. Ako je tijekom sezonskog rada osoba primala plaću od 5000 kuna, onda je realno tvrditi kako će pravo na ZMN moći ostvariti tek nakon 3 mjeseca od primitka zadnje plaće. Nadalje, primjer su i radnici u nisko plaćenim zanimanjima čiji je ugovor o radu otkazan. Ukoliko su primali nisku plaću, nisu mogli štedjeti kako bi se od štednje uzdržavali prije stjecanja prava na podnošenje zahtjeva, a jednako tako, proteći će određeno vrijeme do ispunjavanja uvjeta za ostvarivanje prava na naknadu. Za to vrijeme jedini mehanizam u sprječavanju njihovog dubljeg upadanja u mrežu siromaštva jest jednokratna naknada.

15 Ako se radno sposobni samac ili član kućanstva koji je korisnik prava na ZMN, a koji sudjeluje u radovima za opće dobro iz čl. 39. st. 3. ovog Zakona, zaposli u javnom radu, ZMN samcu ili kućanstvu se ne ukida, odnosno ne umanjuje se za prihod ostvaren po osnovi zaposlenja u javnom radu (Zakon o socijalnoj skrbi, 2017., čl. 40., st. 4.). 
Nadalje, od posljednjih izmjena i dopuna 2018. godine ZMN se ukida samcu ili članu kućanstva ako je samac ili član kućanstva u postupku priznavanja prava dao netočne ili nepotpune podatke o prihodu i imovini o kojima ovisi priznavanje prava ili opseg prava ili nije omogućio centru za socijalnu skrb uvid u prihod i imovinu. Pravo se također ukida i korisniku koji odbije ponuđeni posao, osposobljavanje, prekvalifikaciju, dokvalifikaciju ili samovoljno otkaže ugovor o radu ili ako se ne odazove pozivu jedinice lokalne, odnosno područne (regionalne) samouprave za sudjelovanje u radovima za opće dobro bez naknade (Zakon o socijalnoj skrbi, 2013., 2014., 2015., 2016., 2017.a, 2017.b, čl. 39., st. 1.). Te kategorije korisnika nemaju pravo podnijeti zahtjev za priznavanje prava, odnosno za uvećanje iznosa naknade za kućanstvo u sljedećih šest mjeseci nakon mjeseca u kojem je pravo ukinuto, odnosno u kojemu je pravo umanjeno (Zakon o socijalnoj skrbi, 2013., 2014., 2015., 2016., 2017.a, 2017.b, čl. 39., st. 2.). Takvim rješenjima zakonodavac je nastojao smanjiti zlouporabe naknade od strane radno sposobnog stanovništva te potaknuti njihovu radnu aktivaciju.

Također, još jedna od specifično ugroženih skupina korisnika koje je važno obuhvatiti u kontekstu rasprave o učinkovitosti ZMN-a su beskućnici. Osobe u statusu beskućnika su specifične s obzirom na izraženost višestrukih i kompleksnih potreba, prije svega za stanovanjem, za osiguravanjem sredstava za život i za većim mogućnostima uključenosti u društvo. Zakon o socijalnoj skrbi (2014., 2015., 2017., čl. 29., st. 2.) propisuje kako beskućnici koji su korisnici usluge smještaja u prenoćištu imaju pravo na ZMN. Međutim, beskućnici korisnici privremenog smještaja u prihvatilištu na ZMN nemaju pravo. Tako je od zakonodavca zanemarena činjenica da opseg usluga privremenog smještaja u prihvatilištu zadovoljava samo najuže potrebe korisnika (Družić Ljubotina, Kletečki Radović i Ogresta, 2016.). Takvim zakonskim rješenjem ovoj skupini se dodatno otežava zadovoljavanje osnovnih životnih potreba, a dugoročno se onemogućuje u izlasku iz statusa beskućništva. Prema iskustvima iz prakse, beskućnici koji ne mogu ostvariti pravo na ZMN najčešće podnose zahtjeve za jednokratnu naknadu. Upravo tu činjenicu potvrđuje istraživanje Družić Ljubotina, Kletečki Radović i Ogresta (2016.) prema kojem 50,2\% sudionika (beskućnika) koristi jednokratnu naknadu. Međutim, s jednokratnom pomoći se problemi ne rješavaju, samo gasimo požare. Socijalni radnici na terenu su svjesni problematike i iznimno lošeg položaja ove korisničke skupine u pogledu ostvarivanja prava na ZMN te se aktivno uključuju u zagovaranje njihovih prava. Vrijeme je da zakonodavac posluša glas struke i korisnika!

Kada je riječ o broju korisnika, ZMN je tijekom 2012. godinu (Ministarstvo socijalne politike i mladih, 2013.) koristilo približno 2,6\% stanovništva, a prema posljednjim godišnjim statističkim izvješćima u 2018. godini koristilo ga je približno 1,8\% hrvatskog stanovništva (MDOMSP, 2019.). U zadnjem desetljeću svjedočili smo 
osciliranju broja korisnika od rasta broja korisnika poslije ekonomske krize, a moguće je i da je određeni utjecaj na povećanje imalo i uvođenje veće stope PDV-a koja je povisila životne troškove. Rast broja korisnika ZMN-a nastavlja se do 2013. godine, a konačno 2014. godine svjedočimo padu broja osoba koje ostvaruju pravo na ZMN (Tablica 3.) (MDOMSP, 2015.).

Tablica 3. Kretanje broja korisnika od 2011. do 2018. godine

\begin{tabular}{cccc}
\hline Godina & Broj prava & Broj korisnika & $\begin{array}{c}\text { Jednokratna naknada } \\
\text { (samcima i obiteljima) }\end{array}$ \\
\hline 2011. & 46189 & 104112 & 75367 \\
2012. & 49254 & 110794 & 73195 \\
2013. & 49901 & 113358 & 86682 \\
2014. & 49053 & 101343 & 80714 \\
2015. & 50974 & 102297 & 85661 \\
2016. & 48701 & 97492 & 76412 \\
2017. & 45099 & 84930 & 73560 \\
2018. & 38765 & 72759 & 67692 \\
\hline
\end{tabular}

Izvor: MDOMSP (2012., 2013., 2014., 2015., 2016., 2017., 2018., 2019.)

Jednokratna naknada je druga najvažnija naknada stalne pomoći u sustavu socijalne skrbi ako je suditi prema broju korisnika (1,66\% stanovništva RH (MDOMSP, 2019.)).

Jednokratna naknada priznaje se samcu ili kućanstvu koje zbog trenutačnih materijalnih teškoća nije u mogućnosti podmiriti osnovne životne potrebe nastale zbog rođenja ili školovanja djeteta, bolesti ili smrti člana obitelji, elementarne nepogode i slično (Zakon o socijalnoj skrbi, 2013., 2014., 2015., 2016., 2017.a, 2017.b; čl. 46., st. 1.). Istim člankom propisano je i kako se jednokratna naknada može priznati: zbog nabave osnovnih predmeta u kućanstvu ili nabave nužne odjeće i obuće ako ne postoji mogućnost da se nabava osigura u suradnji s humanitarnim organizacijama; korisniku prava na smještaj u udomiteljsku obitelj koji je učenik osnovne ili srednje škole za kupnju obveznih školskih udžbenika (ako to pravo ne ostvaruje po drugoj osnovi); korisnicima privremenog smještaja u kriznim situacijama radi naknade troškova prijevoza u mjesto prebivališta, vlastitu ili udomiteljsku obitelj, dom socijalne skrbi, kod drugog pružatelja usluge odnosno drugu ustanovu; te iznimno korisnicima usluge smještaja, odnosno organiziranog stanovanja, u slučaju ako potreba za koju se potražuje jednokratna naknada nije zadovoljena u okviru usluge smještaja, organiziranog stanovanja. 
Korisniku se tijekom jedne kalendarske godine može priznati iznos jednokratnih naknada do najviše pet osnovica za samca (2 500 kuna) ili sedam osnovica za kućanstvo (3 500 kuna). Zakonom je uređeno i pravo na uvećanu jednokratnu naknadu koja se može priznati u osobito opravdanim slučajevima uz prethodnu suglasnost nadležnog Ministarstva. Uvećana jednokratna naknada može iznositi najviše do 10 000 kuna. Zakonom je predviđena i mogućnost ostvarivanja prava na jednokratnu naknadu za pogrebne troškove korisnika ZMN-a i korisnika smještaja ili organiziranog stanovanja. Ona se priznaje za pogreb osobe koja nema zakonskog ili ugovornog obveznika uzdržavanja temeljem sklopljenog ugovora o doživotnom ili dosmrtnom uzdržavanju i to: osobe koja je u času smrti korisnik prava ili član kućanstva koje je korisnik prava na ZMN i osobe koja je u času smrti korisnik smještaja ili organiziranog stanovanja. Podmiruju se samo osnovni pogrebni troškovi. Iznos se isplaćuje fizičkoj ili pravnoj osobi koja je platila pogrebne troškove ili pravnoj osobi koja je registrirana za usluge pogreba i izvršava usluge u konkretnom slučaju. Kada osoba ima prihod ili imovinu, CZSS će od nasljednika tražiti povrat pogrebnih troškova.

ZMN i jednokratna naknada dva su najvažnija novčana programa u borbi protiv siromaštva. Ključnu ulogu imaju socijalni radnici u CZSS-ima koji su u svakodnevnom kontaktu s korisnicima tih dvaju prava. Međutim, sve češće se u profesionalnim krugovima raspravlja o njihovoj učinkovitosti i smislenosti. Između ostalih, postavljaju se pitanja: je li jednokratna naknada izgubila svoju svrhu te kako postići ujednačenost kriterija njenog dodjeljivanja u svim CZSS-ima u Hrvatskoj? Koliko prostora socijalni radnici imaju za stručni rad s korisnicima ZMN-a u Hrvatskoj? Stoga ćemo u nastavku specifični fokus staviti na raspravu o njihovoj učinkovitosti i mogućnostima za unaprjeđenje zakonodavnih rješenja i postupanja u praksi.

\section{KAKO POVEĆATI UČINKOVITOST NAKNADA OPĆE SOCIJALNE POMOĆI?}

\section{Radna aktivacija korisnika i mogućnosti unaprjeđenja suradnje institucija}

Dugotrajno korištenje ZMN-a, prema Šućuru (2001.), podrazumijeva korištenje duže od 3 godine, srednjoročno ili prijelazno korištenje znači da ga korisnik koristi od 1 do 3 godine, a kratkoročno do 1 godine. Prema podacima iz statističkih izvještaja MDOMSP-a (2014., 2016., 2017., 2018., 2019.), najčešće se pravo na ZMN koristi u razdoblju od 2 do 5 godina, a najrjeđe u trajanju do 6 mjeseci (vidi Graf 1.). 


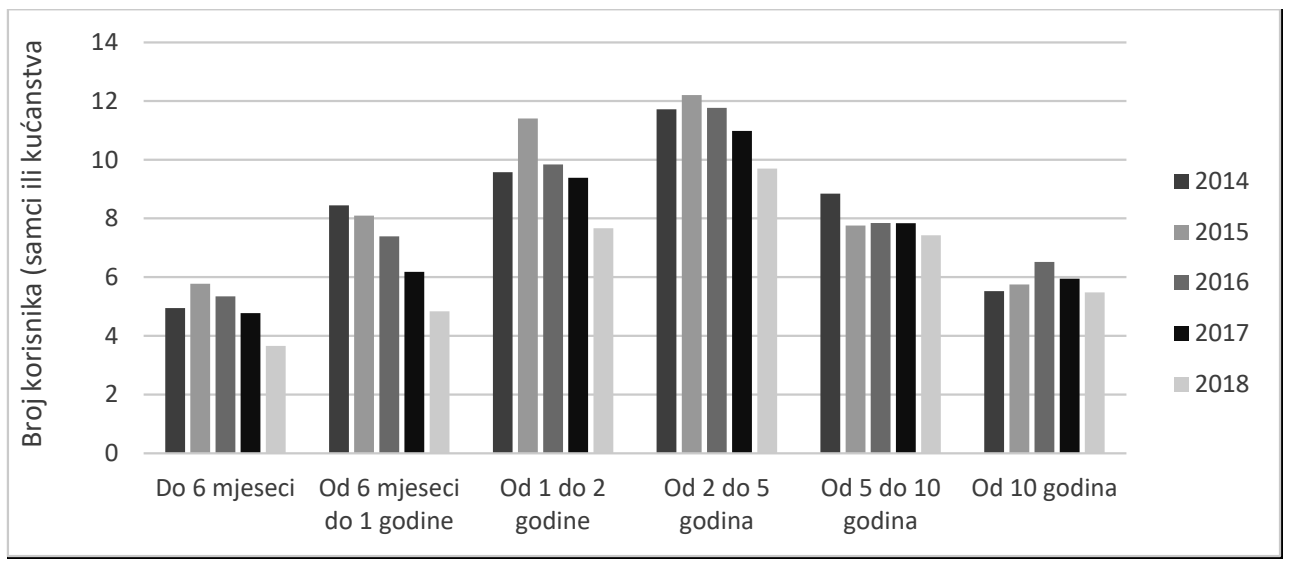

Graf 1. Struktura korisnika prema duljini ostvarivanja prava na ZMN (samci i kućanstva)

Gore navedeni podaci ukazuju kako u Hrvatskoj i dalje postoji velik udio dugotrajnih korisnika ZMN-a. U 2016. godini dulje od 5 godina ${ }^{16}$ ga je koristilo $14,73 \%$ korisnika (samaca i kućanstava), 2017. godine 16,22\%, a 2018. godine 17,74\% korisnika ZMN-a što nam ukazuje na kontinuirani porast broja dugotrajnih korisnika. Drugim riječima, na neučinkovitost države u borbi protiv siromaštva. Istraživanja pokazuju kako se vjerojatnost samostalnog financiranja smanjuje kako raste duljina primanja naknade (Banjedvorec, 2014.) stoga bi u tom kontekstu bilo vrijedno intenzivnije pratiti, stručno pomagati te intenzivirati suradnju državnih institucija.

U pogledu mladih ${ }^{17}$ kojih je u 2017. godini među korisnicima ZMN-a bilo $17,26 \%$ (MDOMSP, 2018.), a 2018. godine 16,23\% (MDOMSP, 2019.) bilo bi važno raditi na njihovom intenzivnijem uključivanju u tržište rada i programe dokvalifikacija, prekvalifikacija. Upravo Europski parlament (2017.) ističe kako bi na razini EU sheme minimalnog dohotka trebale kao prvi i neizbježni cilj imati integraciju mladih siromašnih u tržište rada. Nedovoljni, ali ipak mali pomaci u smanjenju broja korisnika ZMN-a među skupinom mladih jesu uočljivi što moguće možemo povezati i s razvojem programa radne aktivacije mladih. Osim toga, rezultati istraživanja (Družić Ljubotina, Sabolić i Kletečki Radović, 2017.; Kletečki Radović, Vejmelka i Družić Ljubotina, 2017.) pokazuju kako mladi iz siromašnih obitelji kao strategiju borbe protiv siromaštva vide odlazak u ekonomski perspektivnije zemlje u potrazi za poslom. U tom pogledu, uloga države je da u narednom razdoblju iznađe načina kako programe aktivacije učiniti dostupnijima mladima, ali i interesantnijima za korištenje.

\footnotetext{
16 Nedostupni podaci o broju korisnika (samaca i kućanstava) koji su koristili ZMN između 3 i 5 godina.

17 Od 15 do 30 godina starosti.
} 
Tablica 5. Osobe uključene u programe radne aktivacije (2013. - 2018.)

\begin{tabular}{lcccccc}
\hline & 2013. & 2014. & 2015. & 2016. & 2017. & 2018. \\
\cline { 2 - 7 } & 42827 & 28339 & 41595 & 37707 & 37907 & 36935 \\
Novouključeni u mjere & 10829 & 28293 & 23178 & 33021 & 26890 & 31110 \\
$\begin{array}{l}\text { Aktivni korisnici početkom } \\
\text { godine }\end{array}$ & & & & & & \\
\begin{tabular}{l} 
Ukupni korisnici u godini \\
\hline
\end{tabular} & 53656 & 56632 & 64773 & 70728 & 64797 & 68045 \\
\hline
\end{tabular}

Izvor: Hrvatski zavod za zapošljavanje ${ }^{18}$

S preventivnog gledišta, kako bi postigli dugoročni cilj smanjenja udjela mladih u korisnicima ZMN-a, važno je osmisliti programe podrške odrastanju (odgoju i obrazovanju, prehrani itd.) djece iz siromašnih obitelji s ciljem postizanja pozitivnijih životnih ishoda. Naime, kroz kontinuirani integralni stručni rad od najranije dobi mogu se povećati njihove šanse za prekidanjem međugeneracijskog prijenosa siromaštva, pri čemu je paralelan rad s roditeljima na njihovim roditeljskim i socijalnim kapacitetima iznimno važan. Dosadašnja istraživanja (Družić Ljubotina, Sabolić i Kletečki Radović, 2017.; Kletečki Radović, Vejmelka i Družić Ljubotina, 2017.) pokazuju kako mladi iz siromašnih obitelji imaju ograničene mogućnosti izbora škola (najčešće samo u okviru lokalne zajednice), a češće završavaju strukovne trogodišnje obrazovanje (s plaćenom praksom) pri čemu se nerijetko događa da završavaju programe kojima nisu konkurentni na tržištu rada. Upravo se obrazovanje smatra jednim od ključnih elemenata za socijalno uključivanje, a stjecanje viših kvalifikacija otvara veće mogućnosti zapošljavanja i smanjuje opasnost ostajanja u »začaranom krugu« siromaštva (UNDP, 2009.; Wolf, 2007.).

Također, prema posljednjem dostupnom statističkom izvješću za 2018. godinu (MDOMSP, 2019.), udio radno sposobnih, nezaposlenih, korisnika u ukupnom broju korisnika ZMN-a je $48,68 \%{ }^{19}$. Pod vidom toga, intenzivniji stručni rad s radno sposobnim korisnicima, ali i planiranje većeg broja mjera radne aktivacije $(M R A)^{20}$ korisnika ZMN-a jest krucijalno. Europska komisija (2015.) ističe kako je pretežit fokus u pogledu MRA u Hrvatskoj stavljen na mlade i visokoobrazovane osobe za koje je programe jednostavnije planirati i provoditi dok je nedovoljno mjera osmišljeno za korisnike ZMN-a. Vezano uz to, Europski parlament (2017.) ističe kako je u Hrvatskoj važno raditi na promociji MRA. Pri tome je za naglasiti kako je važno planirati programe u koje će korisnici ZMN-a moći biti dugoročno uključeni jer samo kontinuiranim radnim aktiviranjem možemo očekivati pozitivne promjene.

\footnotetext{
18 U nastavku teksta: HZZZ.

19 Ako u obzir uzmemo i kućanice onda je taj postotak i nešto viši $(51,37 \%)$.

20 U nastavku teksta: MRA.
} 
Tablica 6. Struktura korisnika ZMN-a prema radnom statusu

\begin{tabular}{lrrrrr}
\hline SKUPINA KORISNIKA & $\mathbf{2 0 1 4}$ & $\mathbf{2 0 1 5 .}$ & $\mathbf{2 0 1 6 .}$ & $\mathbf{2 0 1 7 .}$ & $\mathbf{2 0 1 8 .}$ \\
\hline Zaposleni & 857 & 808 & 585 & 426 & 494 \\
Nezaposleni & 52300 & 50378 & 49854 & 40766 & 35416 \\
Umirovljenici & 1009 & 1349 & 2022 & 2162 & 2344 \\
Kućanica & 3057 & 2410 & 2624 & 2181 & 1959 \\
Dijete & 11059 & 11343 & 11029 & 9609 & 7178 \\
Učenik & 17047 & 18635 & 16075 & 14360 & 11789 \\
Student & 812 & 947 & 1177 & 942 & 712 \\
Nesposoban za rad & 8508 & 9836 & 9166 & 9954 & 9310 \\
Odrasla potpuno radno nesposobna & & & & 4530 & 3557 \\
(ne umirovljenik) & 6694 & 6591 & 4960 & & \\
\hline UKUPNO: & $\mathbf{1 0 1 3 4 3}$ & $\mathbf{1 0 2 ~ 2 9 7}$ & $\mathbf{9 7 4 9 2}$ & $\mathbf{8 4 9 3 0}$ & $\mathbf{7 2 ~ 7 5 9}$ \\
\hline
\end{tabular}

Izvor: MDOMSP (2015., 2016., 2017., 2018., 2019.).

Prema EMIN-u (2017.), 10,5\% populacije EU-a u dobi od 0 do 59 godina živi u kućanstvima s niskom razinom radnog intenziteta dok u Grčkoj, Španjolskoj, Belgiji i Hrvatskoj oko $15 \%$ ljudi živi u kućanstvima s vrlo niskim radnim intenzitetom ${ }^{21}$. Učinkovitost u provedbi MRA, individualna uloga, opterećenje i odgovornost voditelja slučaja (socijalnog radnika i savjetnika u HZZ-u) stoga su ključni čimbenici (SPC, 2015.) u smanjenju nezaposlenosti radno sposobnih korisnika ZMN-a. U Irskoj nezaposlene radno sposobne osobe moraju surađivati sa stručnjacima u kreiranju osobnog plana promjene i koristiti navedeni plan kako bi išli u smjeru sigurnog zaposlenja (Europski parlament, 2017.). Kod nas tu ulogu preuzima HZZ, no smatramo važnim personalizirati pristup izradama i praćenju provedbe planova, ali i sustavnije kontrolirati ispunjavanje obveza javljanja na natječaje. Sadašnja iskustva iz svakodnevnog praktičnog rada s korisnicima sugeriraju na činjenicu kako nedostaje sustavno praćenje izvršavanja obveza traženja posla nezaposlenih osoba. Aplikacija SocSkrb uvelike je olakšala rad u CZSS-ima posebno u pogledu umreženosti s drugim institucijama (Porezna uprava, HZZZ itd.). Međutim, i dalje imamo radno sposobne korisnike ZMN-a koji se dugogodišnje vode kao nezaposleni. U tom kontekstu, Europska komisija (2015.) i Europski parlament (2017.) naglašavaju slabu koordinaciju između različitih aktera koji su uključeni u pružanje usluga i naknada u Hrvatskoj. U pogledu suradnje s HZZZ-om,

${ }^{21}$ U engleskom govornom području koristi se pojam jobless housholds. On podrazumijeva kućanstva gdje odrasle osobe koriste manje od $20 \%$ ukupnog radnog potencijala unazad nekoliko godina. 
moguće je učiniti poboljšanja tako da socijalni radnici budu povezaniji sa savjetnicima za zapošljavanje njihovih korisnika kako bi mogli dodatno ih motivirati da se jave i eventualno zaposle. Tada bi i individualno planiranje s korisnicima i osnaživanje za radnu aktivaciju, postizanje životnih promjena bilo olakšano.

Nastavno, zakon propisuje kako je obveza HZZZ-a u roku od 8 dana obavijestiti CZSS o činjenici da je (djelomično) radno sposobna osoba izgubila status nezaposlene osobe, no u praksi se ti rokovi ne poštuju22. Zakon obvezuje korisnike i na redovito javljanje HZZZ-u te prihvaćanje ponuđenih poslova, no dugotrajno korištenje naknade vodi k pitanju: je li to dovoljno? U praksi se nerijetko događa da radno sposobne osobe, korisnici ZMN-a, ostaju prijavljeni na HZZZ-u dugi niz godina bez da aktivno rade na rješavanju svog radnog statusa ili obvezu javljanja na natječaje ispunjavaju samo fiktivno kako bi zadržali novčanu naknadu iz sustava socijalne skrbi. U tom pogledu, bilo bi važno razvijati suradnju HZZZ-a i poslodavaca u smislu izvještavanja o osobama koje su prijavu na natječaj poslale pro forme, a uz to i HZZZ-a sa CZSS-ima s ciljem smanjivanja broja osoba, korisnika ZMN-a, koji izbjegavaju zapošljavanje. Na primjer, istraživanje Družić Ljubotina, Kletečki Radović i Ogresta (2016.) pokazalo je kako su nezaposleni beskućnici većinom prijavljeni na HZZZ-u $(73,4 \%)$, međutim $29 \%$ beskućnika koji su sudjelovali u njihovom istraživanju uopće ne traži posao. U tom pogledu, odgovornost je i savjetnika za zapošljavanje djelovati u smjeru njihove jače aktivacije i poticanja na zapošljavanje, ali i na senzibilizaciju poslodavaca da se odluče pružiti priliku osobi koja je u statusu beskućnika. Osim toga, gledajući općenito kontekst radno sposobnih korisnika ZMN-a, bilo bi potrebno da poslodavci povratno izvijeste $\mathrm{HZZ}$ o motiviranosti korisnika za zapošljavanje kako bi se spriječile zlouporabe, tj. da korisnici pro forme traže posao. Ovdje je važno za istaknuti i kako su neka istraživanja pokazala kako tipični slučaj dugotrajnog primanja ZMN-a vjerojatno nije činjenica da je naknada dovoljno izdašna da destimulira zapošljavanje, već na tržištu postoji mala potražnja za niskokvalificiranim radnicima kakvi su većinom korisnici ZMN-a (Rubil, Stubbs i Zrinščak, 2018.). Osim toga, korisnici ZMN-a smatraju kako zaposlenja koja se nude ne donose financijsku sigurnost pa je život na socijalnoj pomoći puno »privlačniji« (Družić Ljubotina, Sabolić i Kletečki Radović, 2017.). Teško je za povjerovati da bi osoba odabrala višegodišnje spajanje kraja s krajem pomoću novčanih naknada kada bi mogla ostvariti zaposlenje koje će donijeti zaradu višu od potrebne za zadovoljavanje egzistencijalnog minimuma (Rubil, Stubbs i Zrinščak, 2018.). S obzirom da to tržište rada ne omogućuje, korisnici nerijetko pribjegavaju strategijama preživljavanja koje ponajviše uključuju obavljanje povremenih poslova u sivoj ekonomiji (Rubil, Stubbs i Zrinščak, 2018.; Družić Ljubotina, Sabolić i Kletečki Radović, 2017.). Sukladno tome, stroža kontrola neformalnih ekonomskih aktivnosti,

${ }^{22}$ Govorimo o Zagrebu. Ostavlja se mogućnost da je u manjim sredinama izvještavanje uredno. 
iako bi donijela fiskalnu korist, najviše bi pogodila najsiromašnije, a ako bi vlast bila odlučna u takvom naumu, bile bi potrebne kompenzacijske mjere (Rubil, Stubbs i Zrinščak, 2018.).

Isto tako, u Zakonu o socijalnoj skrbi (2017.) navodi se obveza razmjene podataka između CZSS-a te lokalne i područne samouprave o radno sposobnim korisnicima, no iz prakse je poznato kako CZSS-i redovito šalju popise, no u gradu Zagrebu specifično se javni radovi rijetko ili gotovo nikako ne provode. $S$ druge strane naglašavaju kako je suradnja dionika i učinkovitost provedbe mjera javnih radova veća u manjim sredinama. Dakle, i u pogledu izvršavanja zakonskih obveza postoje razlike među lokalnim jedinicama pa bi vrijedilo poraditi na dosljednosti njihovog provođenja. Babić (2012.) navodi kako je u periodu od 2006. do 2008. i 2009.-2010. stopa uključenosti ciljanih sudionika u mjere aktivne politike svega 1-2\%. Slično, Europska komisija (2015.) ističe kako je mali udio korisnika ZMN-a uključen u MRA, a pretežno su uključeni u program javnih radova koji se čini najmanje učinkovitim u povećavanju zapošljivosti (Winden i sur., 2002., prema Bejaković, 2016.).

\section{Visina naknada i njihova ciljanost}

Iznos osnovice rijetko se mijenjao, odnosno usklađivao s troškovima života. S obzirom na liniju siromaštva, osnovica je vrlo nisko postavljena (Banjedvorec, 2014.). Posljednji put mijenjala se 2014. godine kada se odlukom Vlade iznos povisio s 500 na 800 kuna. Prema pokazateljima siromaštva i socijalne isključenosti u 2018. (DZS, 2019.), prag rizika od siromaštva ${ }^{23}$ za jednočlano kućanstvo iznosio je 29820 kuna na godinu (2 485 kuna mjesečno), a za kućanstvo s dvije odrasle osobe i dvoje djece mlađe od 14 godina 62622 kune godišnje (5 218,50 kune mjesečno). Istodobno, visina iznosa ZMN-a za samca iznosi 800 kuna, a radno nesposobnog 920 kuna što je daleko ispod ranije navedenih iznosa i gotovo ispod svakog dostojanstva. ZMN pokriva samo između 32\% i 46\% egzistencijalnih potreba kućanstava (Stubbs i Zrinščak, 2015.). U najslabije razvijenim shemama minimalnog dohotka (Bugarska, Rumunjska, Poljska, Latvija) naknade za samca pokrivaju između $24 \%$ i $29 \%$ linije rizika od siromaštva dok u najizdašnijim (npr. Belgija, Danska, Nizozemska, Austrija) one pokrivaju između 71\% i $91 \%$ (121\% u slučaju Irske) (Europska komisija, 2015.). Prema podacima Europske komisije (2015.) Hrvatska je jedna od zemalja gdje naknada (ZMN) ne pokriva niti troškove osnovne prehrambene košarice. Neadekvatnost programa minimalnog dohotka (kakav je i ZMN) da osigura dostojan životni standard poseban je izazov

${ }^{23}$ Prag rizika od siromaštva postavljen je na $60 \%$ od srednje vrijednosti (medijana) ekvivalentnoga raspoloživog dohotka svih osoba. 
mnogim državama, a u samo 5 država (Češka, Nizozemska, Cipar, Litva i Island) razina naknade je odgovarajuća (Europska komisija, 2015.).

Pozitivna činjenica je da se na ZMN vezuju druga prava poput naknade za ugroženog kupca energenata (200 kuna mjesečno) i specifično za Grad Zagreb naknada troškova stanovanja (u slučaju sklopljenog ugovora o najmu ili vlasništva stana) (480 kuna mjesečno) što korisnicima omogućuje zadovoljavanje osnovnih životnih potreba u većoj mjeri. Korisnici za podmirenje prehrambenih potreba mogu koristiti pučku kuhinju ili Caritasove pakete hrane. Pa, iako navedena druga prava donekle povećavaju učinkovitost ZMN-a, ta povećanja nisu toliko značajna. Prema podacima Rubila, Stubbsa i Zrinščaka (2018.), korisnici ne uspijevaju osigurati iznos novčanih primanja potreban za potpuno zadovoljenje osnovnih potreba čak i kada uz ZMN primaju i neke druge naknade. Također, moramo uzeti u obzir da je Grad Zagreb specifičan po brojnosti socijalnih programa koje nudi svojim građanima. Nažalost, situacija nije takva u svim područjima Republike Hrvatske, a raznolikost i izdašnost dodatnih naknada ovise prvenstveno o veličini budžeta s kojim lokalne zajednice raspolažu. Prema rezultatima izvještaja Centra za mirovne studije (2016.: 1), u Hrvatskoj su uočljive velike razlike između tzv. razvijenijih dijelova Hrvatske (Grad Zagreb, Istarska, Primorsko-goranska, Varaždinska i Međimurska županija) i slavonskih županija (Vukovarsko-srijemska, Osječko-baranjska, Brodsko-posavska, Požeško-slavonska). Razlika između najniže i najviše stope rizika od siromaštva na razini županija potvrđuje velike regionalne razlike: najmanja je u Gradu Zagrebu (9,82), a najviša u Brodsko-posavskoj gdje iznosi visokih 35,8 (Centar za mirovne studije, 2016.: 3). Županije s najvišim stopama rizika od siromaštva su Virovitičko-podravska, Sisačko-moslavačka, Vukovarsko-srijemska, Osječko-baranjska, Bjelovarsko-bilogorska, Brodsko-posavska i Požeško-slavonska županija. Prema najnovijim podacima Državnog zavoda za statistiku (2019.) stopa rizika od siromaštva za Jadransku Hrvatsku u 2018. iznosila je $18,4 \%$ dok je za kontinentalnu Hrvatsku iznosila $19,7 \%$. Stupanj ostvarenja socijalnih prava i socijalne sigurnosti stanovništva Republike Hrvatske uvelike ovisi o mjestu stanovanja. Navedeno je opozitno temeljnom načelu jednakosti građana u ostvarivanju socijalnih prava na čitavom teritoriju države. Babić (2016.) tvrdi kako ne samo da je socijalna situacija građana ovisna o mjestu stanovanja, nego i da su određeni socijalni programi decentralizirani te županije i gradovi mogu na svom teritoriju u skladu s načelom supsidijarnosti provoditi vlastite dodatne programe socijalne politike. Tako svjedočimo kontradiktornostima: razvijenije lokalne jedinice s manjim brojem siromašnog stanovništva imaju istodobno brojnije i izdašnije socijalne programe od nerazvijenijih s većim potrebama za socijalnim programima, a manjim budžetom (Babić, 2016.). Iskustva iz prakse pokazuju nam kako korisnici, posebice u lošije razvijenim krajevima, sve češće koriste jednokratne naknade za podmirivanje osnovnih životnih potreba poput prehrane, plaćanje režija i slično. Navedeno nam ukazuje na neučinkovitost ZMN-a čak i u kombinaciji s drugim pravima. Socijalni radnici 
zaposleni na odjelima novčanih naknada učestalo na stručnim skupovima ukazuju na gubitak smisla jednokratnih naknada te doživljaj da upravo dodjelom jednokratnih naknada pokušavaju korisnike izvući iz vrtloga siromaštva. Međutim, postoji svjesnost kako se dodjelom jednokratne samo gasi trenutni požar, a nikako ne uspijeva korisnike izdignuti iznad linije siromaštva. Upravo iz tog razloga, važno je povećati iznose ZMN-a jer u ovakvim iznosima jedva osigurava osnovnu egzistenciju. Pri tome su u posebno lošem položaju podstanari korisnici ZMN-a. Naime, Zakon trenutno ne prepoznaje razliku između podstanara i vlasnika nekretnine čime se vlasnici dovode u povoljniji položaj. Stopa rizika od siromaštva u 2018. godini veća je za podstanare i iznosi $29,7 \%{ }^{24}$ nego za vlasnike nekretnine za koje iznosi $18,9 \%$ (DZS, 2019.). Stoga bi bilo važno kreirati posebne naknade ili dodatke na iznos ZMN-a ovisno o specifičnim potrebama ili karakteristikama korisnika. Na primjer, uvesti dodatne iznose vezivne na ZMN za osobe koje su u statusu podstanara (stambene subvencije) koji bi bili definirani na nacionalnoj razini te bi se isplaćivala iz sredstava državnog proračuna. Jedna od mogućnosti je i kategorizacija područja Hrvatske sukladno troškovima života s obzirom na činjenicu da troškovi variraju i nije jednako biti siromašan u Splitu ili Požegi, odnosno biti podstanar u Zagrebu ili Slavonskom Brodu (DZS, 2019.). Lokalnim jedinicama bi moglo biti omogućeno da ovisno o financijskim mogućnostima osiguraju svojim stanovnicima dodatnu podršku u pogledu stambenih subvencija. Pri planiranju zakonskih izmjena bilo bi važno konzultirati i same korisnike. Također, bilo bi nužno na razini Hrvatske raditi godišnje procjene radi usklađivanja visine naknade (ZMN-a) vodeći računa o razini potrebnog minimalnog dohotka za najrelevantnija kućanstva (samce, samohrane roditelje, par s dvoje djece i velike obitelji), minimalnoj plaći te stvarnim troškovima sudjelovanja u društvu.

\section{Mogućnosti unaprjeđenja rješenja u pogledu djece i umirovljenika}

Od 1. siječnja 2014. godine ukinute su razlike u visini naknade s obzirom na dob djeteta te se uvodi unificirani postotak od $40 \%$ osnovice. Rubil i sur. (2018.) ističu kako promjena nije vodila računa o činjenici da se dječje potrebe s rastom dobi povećavaju. Samim time, kao što je ranije već istaknuto, obitelji s većim brojem djece (3 i više) ${ }^{25}$ stavljaju se u nepovoljniji položaj (Banjedvorec, 2014.) te sada po djetetu ostvaruju od 80 do 180 kuna manje. Policy brief Stubbsa i sur. (2017.) pokazao je kako najveći rizik imaju upravo djeca koja žive u kućanstvima s većim brojem djece.

\footnotetext{
24 Povećanje od 2 postotna boda u odnosu na 2016. godinu.

25 U 2017. godini obitelji s troje i više djece činile su 36,69\% kućanstava korisnika ZMN-a (DZS, 2018.).
} 
Dječje siromaštvo u Hrvatskoj posebno zabrinjava i iz razloga što je stopa dugotrajnog siromaštva djece iznad 2,2\% europskog prosjeka, a Hrvatska je i u skupini zemalja s najvišim stopama djece koja u siromaštvu provedbu četiri godine za redom (Stubbs i sur., 2017.). Istraživanje Rubila, Stubbsa i Zrinščaka (2018.) pokazalo je kako prosječna mjesečna novčana primanja po članu kućanstva korisnika ZMN-a iznose vrlo niskih 758 kuna, dok je medijan nešto niži (740 kuna). S tako niskim prihodima teško se može osigurati čak i minimalni materijalni standard i to posebice ako uzmemo u obzir činjenice da je prosječni minimum potreban da kućanstvo »spoji kraj s krajem « $83 \%$ veći od prosječnih novčanih primanja (Rubil, Stubbs i Zrinščak, 2018.). Stubbs i sur. (2017.) stoga ističu kako je važno povećati iznos ZMN-a te vratiti ranije važeće razvojno prilagođene koeficijente s kojima se množila osnovica. Nezanemariv je udio djece i maloljetnika kao korisnika ZMN-a (vidi Graf 2.) što dodatno govori u prilog potrebi povećanja adekvatnosti ZMN-a. Naime, u 2018. godini je među korisnicima ZMN-a bilo 27,50\% djece (20 004) (MDOMPS, 2019.).

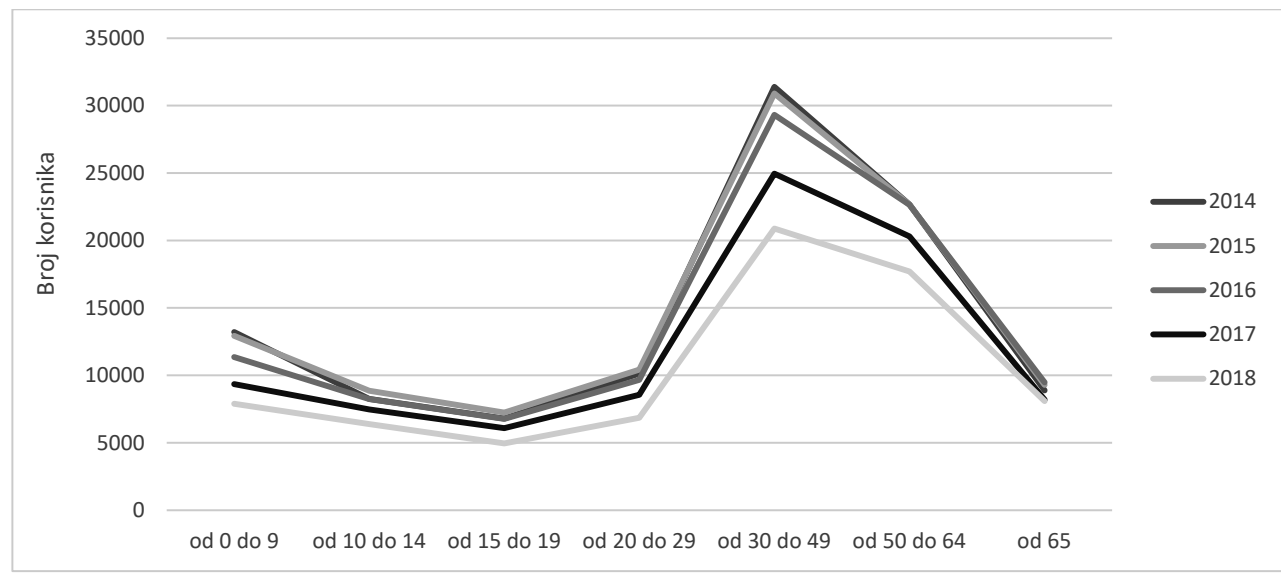

Izvor: MDOMSP (2015., 2016., 2017., 2018., 2019.)

Graf 2. Kretanja u strukturi korisnika ZMN-a prema dobi

U prilog potrebi povećanja iznosa naknade za djecu i diferencijacije iznosa govori činjenica da se korisnici često obraćaju zahtjevima za jednokratne naknade za podmirenje troškova vezanih uz dječje potrebe (npr. troškovi školskih izleta, nabavka školske opreme, odjeće i drugog). Navedeno potvrđuju i nalazi UNICEF-ove istraživačke studije "Siromaštvo i dobrobit djece predškolske dobi u Republici Hrvatskoj» (2015.). Studija je pokazala da 82,5\% djece živi u kućanstvima koja nisu u mogućnosti podmiriti iznenadne financijske izdatke. Kao posebne teškoće roditelji u studiji, između ostalih, navode i veću usmjerenost na potrebe školske nego predškolske djece, 
problem plaćanja različitih davanja za školu, poteškoće i potrebe u osiguranju hrane i odjeće i drugo.

Kao dobri primjeri mogu nam poslužiti Finska i Češka gdje se uvažava razlika u dobi u kreiranju ekvivalentne ljestvice. Tako u Finskoj djeca mlađa od 10 godina mogu ostvariti naknadu od 305 eura, od 10 do 17 godina 340 eura, a dijete od 18 ili više godina koje živi s roditeljima 354 eura (Europski parlament, 2017.). U Češkoj djeca mlađa od 6 godina primaju naknadu u visini od 64 eura, od 6 do 15 godina 79 eura, a od 15 do 26 godina 90 eura (Europski parlament, 2017.). Dakle, preporučamo u Hrvatskoj ili povećati naknade za djecu (povećanje postotka osnovice) ili vratiti diferencijaciju prema dobi.

Druga, posebno ugrožena, skupina stanovništva u Republici Hrvatskoj su umirovljenici. Prema Šućur (2008.), starije osobe bez mirovina predstavljaju posebno ranjivu i socijalno rizičnu skupinu te su prisiljeni tražiti socijalnu pomoć. Dosadašnja istraživanja (DZS, 2007.; Šućur, 2005.; World Bank, 2006., prema Šućur, 2008.) potvrdila su da starije osobe u Hrvatskoj čine skupinu povećanog rizika od siromaštva. Prema DZS-u (2018.), $21,8 \%$ umirovljenika je u riziku od siromaštva. Dostupnost naknada socijalne pomoći uvijek ovisi o provjeri dohodovnog i imovnog stanja potencijalnih korisnika (Šućur, 2005.), a Banjedvorec (2014.) ističe kako je najočitiji problem ZMN-a niski cenzus koji mnoge građane koji se nalaze u riziku od siromaštva isključuje iz kruga korisnika. Udio umirovljenika u ukupnom broju korisnika ZMN-a, prema posljednjem godišnjem statističkom izvješću (MDOMSP, 2019.), iznosio je oko 3,2\% (2 344). S druge strane, 180983 umirovljenika prima mirovinu manju od 1000 kuna, a 478893 ih prima mirovinu manju od 2000 kuna (42\% ukupnog broja umirovljenika) (HZMO, 2018.). Takvi podaci ukazuju kao prvo na činjenicu kako se vjerojatno određeni broj umirovljenika koji bi eventualno mogli ostvariti pravo na ZMN ne obraća zbog neinformiranosti, stigme i drugih razloga. Stoga je potrebno razvijati lokalne programe pomoću kojih ćemo detektirati umirovljenike koji žive u siromaštvu kako bi se osigurala veća pokrivenost naknadama. S druge strane, oni s mirovinama preko zakonom propisanih iznosa ne ispunjavaju uvjete iako nemaju dovoljno sredstava za život. U tom slučaju, koriste povremene jednokratne naknade. I u tom pogledu, važno je umrežavanje s NGO sektorom koji bi razvijao programe ili usluge na dobrobit te skupine umirovljenika, ali i razmišljanje o snižavanju prihodovnih uvjeta za ostvarivanje ZMN-a u pogledu umirovljenika.

\section{ULOGA STRUKE SOCIJALNOG RADA}

Zbog brojnih zakonskih i podzakonskih akata kojima se moraju voditi u svom radu, stručni radnici CZSS-a često se u javnosti doživljavaju kao mehanizam državne kontrole, s naglaskom na pronalaženje zlouporaba umjesto na kvalitetu stručnog rada. 
Slično, Murphy, Duggan i Joseph (2013.: 708, prema Hansen i Natland, 2016.) ističu kako politički i profesionalni kontekst u kojem rade socijalni radnici zahtijevaju od praktičara instrumentalno ponašanje u korist države. Navedeno ograničava mogućnosti djelovanja stručnjaka u prevladavanju teškoća korisnika. Stručnjaci iz područja socijalnog rada u posljednje vrijeme sve snažnije progovaraju o potrebi smanjenja administrativnih opterećenja CZSS-a kako bi se otvorio prostor za stručni rad jer bi na taj način podigli kvalitetu pružanja usluga korisnicima. Rezultati malobrojnih istraživanja (Becker i MacPherson,1988.; Davis i Wainwright, 2005., prema Družić Ljubotina, 2013.) pokazuju kako socijalni radnici nemaju dovoljno vremena da bi bili uključeni u borbu protiv siromaštva, a to posebno zabrinjava s obzirom da su osobe koje žive u siromaštvu najzastupljenija populacija korisnika (Healy, 2001., prema Družić Ljubotina i Kletečki Radović, 2011.). Pod tim vidom, nužno je poboljšati radne uvjete i to na način da se poveća broj zaposlenika, a prethodno tome poduzmu koraci i k unaprjeđenju fizičkih uvjeta rada (osiguravanje prostora za rad te potrebne opreme za nove zaposlenike). Navedeno bi dovelo do smanjenja broja korisnika po socijalnom radniku, a onda i omogućilo kvalitetniji rad sa svakim pojedincem. S korisnicima bi se učestalije izrađivali individualni planovi, što je sa sadašnjim administrativnim opterećenjima značajno otežano, vremenski period koji možemo posvetiti jednom korisniku bi se produžio te bi se moglo redovitije ostvarivati međusobni kontakti s ciljem osnaživanja za razvijanje samopomoći, pomoći u suzbijanju socijalnih i osobnih problema, uključivanja u zajednicu i praćenja korisnika kroz proces promjene.

Također, u CZSS-u se, osim o ZMN-u i jednokratnim naknadama, rješava i, između ostalog, o naknadi do zaposlenja koju je nužno potrebno vratiti u nadležnost zavoda za zapošljavanje. U praksi se na ovaj način događa da se korisnik ne javi CZSS-u kada se zaposli, zavod za zapošljavanje, također, ne obavijesti CZSS, a kada nakon određenog vremena socijalni radnik u CZSS-u provjeri status učestalo se događa da korisnici moraju vraćati bespravno isplaćene iznose naknade. Osim toga, sam naziv prava sugerira da isto treba biti u nadležnosti sustava zapošljavanja. Kada bi naknada do zaposlenja bila u nadležnosti zavoda za zapošljavanje, ono bi se moglo automatizmom prekidati, izbjegle bi se administrativne komplikacije kao i postupci naknada šteta. Drugi set novčanih naknada koji opterećuje socijalne radnike u CZSS-ima su naknade koje se ostvaruju po osnovi zdravstvenog statusa: osobna invalidnina i doplatak za pomoć i njegu. Zdravstveni sustav trebao bi preuzeti rješavanje o tim naknadama, odnosno Zavod za vještačenje, profesionalnu rehabilitaciju i zapošljavanje osoba s invaliditetom. Naime, to tijelo vještači osobe u postupcima rješavanja o priznavanju navedenih novčanih prava pa sama logika nalaže da isto tijelo izdaje i rješenje o priznavanju. Kada bi se naknada do zaposlenja, osobna invalidnina te doplatak za pomoć i njegu premjestili u nadležne druge sustave, CZSS-u imali bi više vremena za stručni rad. Tada bi, kako je ranije istaknuto, imali više vremena za izradu indivi- 
dualnih planova, savjetovanje o mogućnostima unaprjeđenja životnog standarda, o racionalnom raspolaganju novčanih sredstava i izradi osobnih financijskih planova s kratkoročnim i dugoročnim ciljevima. Međutim, u sustavu kako je sada postavljen, socijalni radnici u CZSS-ima, uslijed iznimno opterećujućih administrativnih zahtjeva, nametnutih poslova te strogih zakonskih cenzusa, nemaju uvijek mogućnost osobama u potrebi istinski pružiti (kontinuiranu) podršku. Tako se svakodnevno u svom radu nalaze u raskoraku između zakonskih propisa, osnovice koja je toliko niska da korisnicima ne omogućava niti približno zadovoljavanje osnovnih životnih potreba te njihove diskrecijske ocjene kao stručnjaka.

Kao jedan od modela rada s osobama u riziku od siromaštva nameće se socijalno mentorstvo koje se temelji na mentorskom i suradničkom odnosu socijalnog mentora i pojedinca u riziku od socijalne isključenosti. Kroz mentorstvo se radi na jačanju sposobnosti i potencijala mentorirane osobe s ciljem napredovanja i bolje integracije u zajednicu što zapravo i jest jedna od uloga socijalnih radnika u odjelu novčanih naknada. Vuković (2019.) socijalno mentorstvo definira kao partnerstvo usmjereno na osnaživanje korisnika, kako bi utjecali na svoj socijalni status, napredujući iz isključenosti u uključenost. Temelji se na individualiziranom pristupu pri čemu je naglasak stavljen na proces planiranja (izradu individualnih planova s korisnicima, praćenje i evaluaciju). Za kvalitetno provođenje socijalnog mentorstva važna je suradnja na lokalnoj razini, dobra informiranost o resursima lokalne zajednice te poticanje širenja mreže usluga. lako Vuković (2019.) navodi kako se socijalno mentorstvo pokazalo pozitivnim rješenjem, takav model rada mogao bi biti teško u potpunosti primjenjiv i provediv u sustavu socijalne skrbi na čitavom području Republike Hrvatske s obzirom na neučinkovite naknade, nedovoljno razvijeno tržište rada, nestimulativne plaće koje bi korisnici ZMN-a na tržištu mogli ostvariti te prekobrojna administrativna opterećenja stavljena na socijalne radnike u javnom sektoru.

Nadalje, etičkim kodeksom socijalnih radnika (Hrvatska komora socijalnih radnika, 2015.) propisano je kako socijalni radnici trebaju predlagati i poduzimati inicijative u području zakonodavstva i socijalne politike koje su u interesu korisnika i profesionalne zajednice. Međutim, u radne skupine za izrade novih ili izmjene postojećih zakona rijetko se uključuju praktičari. Čak i kada su bili uključeni, mogućnost utjecaja na donošenje odluka pokazala se minornom. Redovito su u radne skupine uključeni stručnjaci (socijalni radnici) zaposleni u MDOMSP-u s malo iskustva rada u praksi ili koji već dugi niz godina nisu u praksi. Sukladno tome, važno bi bilo uključivati više praktičara zaposlenih na odjelima novčanih naknada s dugogodišnjim iskustvom.

Međutim, važno je osvrnuti se i na problem pasivizacije struke te nastojati poticati veću aktivaciju, ali i homogenost među profesionalcima i zajedničko zastupanje profesije. Stoga je važno kontinuirano promišljati i unaprjeđivati sustav selekcije kandidata za upis na fakultet socijalnog rada, na akademskoj razini djelovati kako bi 
u budućnosti imali stručnjake koji će biti spremniji u većoj mjeri angažirati se u radu strukovnih organizacija i dizati svoj glas prilikom izmjena zakonodavnih rješenja i planiranju mjera socijalne politike, ali i u aktivnostima civilnog društva koji je značajan dionik. Također, da bi u sustav ulazili bolje pripremljeni mladi stručnjaci, potrebno je u fakultetskom osoblju povećati postotak djelatnika s iskustvom rada u CZSS-ima. A važno je i kontinuirano profesionalno usavršavanje. Ulaganju u stjecanje novih i unaprjeđenje postojećih vještina, znanja, tehnika i sposobnosti trebali bi težiti svi socijalni radnici. Od iznimne važnosti tako vidimo praćenje zakonodavnih procesa, kritičko promišljanje o njima i korištenje resursa strukovnih organizacija kako bi djelovali na političke strukture.

\section{ZAKLJUČAK}

Profesija socijalnog rada svoje temelje izgradila je na borbi protiv siromaštva i borbi za ljudska prava. U Hrvatskoj CZSS-i predstavljaju ključnu ustanovu socijalne skrbi u tom području, a specifično odjeli novčanih naknada na kojem socijalni radnici rade isključivo s ljudima s financijskim problemima. Socijalnim radnicima na raspolaganju stoje zakonski propisani programi opće i kategorijalne novčane pomoći. Fokus ovog rada stavljen je na opće novčane naknade te prednosti i nedostatke njihovog zakonskog uređenja.

Implikacije proizašle iz sadržaja ovog rada sugeriraju kako je radi povećanja učinkovitosti ZMN-a u budućnosti potrebno uvesti stambene subvencije u okviru ZMN-a za osobe u podstanarskim statusima, kategorizirati područja Hrvatske sukladno troškovima života i navedeno primjenjivati u odmjeravanju visine naknade, raditi godišnje usklađivanje visine naknade vodeći računa o razini potrebnog minimalnog dohotka, minimalnoj plaći te stvarnim troškovima sudjelovanja u društvu.

Jednokratna naknada, kako se u praksi čini, polako gubi svoj smisao upravo zbog neučinkovitosti ZMN-a u borbi protiv siromaštva. Korisnici se sve češće obraćaju sa zahtjevima za jednokratnu naknadu i zbog razloga koji spadaju u najosnovnije ljudske potrebe, poput hrane ili lijekova. U tom smislu, država bi se trebala pobrinuti za povećanje osnovice za izračunavanje visine ZMN-a, odnosno za njeno prilagođavanje trenutnom životnom standardu. Potrebno je dosljednije provoditi zakonske odredbe vezane uz radnu aktivaciju, poboljšati suradnju ključnih institucija i kreirati MRA za korisnike ZMN-a. A specifično, vratiti diferencijaciju iznosa naknade prema dobi djece te ojačati programe NGO-a na lokalnim razinama kako bi kao društvo bolje odgovorili na potrebe umirovljenika koji žive u siromaštvu. Ono o čemu treba i nadalje promišljati jest kako radno aktivirati preostale radno sposobne korisnike? Kako ostvariti bolju suradnju lokalnih i regionalnih (područnih) samouprava i zavoda za zapošljavanje sa centrima za socijalnu skrb s ciljem smanjenja broja osoba koje žive u siromaštvu? 


\section{LITERATURA}

1. Babić, Z. (2008). Redistribucijski učinci socijalnih transfera u Republici Hrvatskoj. Revija za socijalnu politiku, 15 (2), 151-170, https://doi. org/10.3935/rsp.v15i2.766.

2. Babić, Z. (2012). Aktivna politika tržišta rada: Europski kontekst i hrvatska praksa. Socijalna ekologija: časopis za ekološku misao i sociologijska istraživanja, 21 (1), 31-52.

3. Babić, Z. (2016). Smanjiti nejednakost u hrvatskom društvu: Zašto siromah u Zagrebu bolje stoji nego onaj u Gundincima? Preuzeto s: https://www. glas-koncila.hr/zasto-siromah-u-zagrebu-bolje-stoji-nego-onaj-u-gundincima/ (2.5.2020.).

4. Banjedvorec, I. (2014). Trendovi i adekvatnost programa opće socijalne pomoći u Republici Hrvatskoj. Socijalna politika i socijalni rad, 2 (1), 82-99.

5. Bejaković, P. (2016). Razvoj mjera aktivne politike zapošljavanja u Hrvatskoj i njihova evaluacija. Revija za socijalnu politiku, 23 (2), 285-294, https:// doi.org/10.3935/rsp.v23i2.1361.

6. Centar za mirovne studije (2016). Nejednakosti u Hrvatskoj. Ekonomija i regionalne nejednakosti. Izvještaj sa policy preporukama. Preuzeto s: http://nejednakost.cms.hr/wp-content/uploads/2016/09/NEJEDNAKOSTI-U-HRVATSKOJ-ekonomija.pdf (2.5.2020.).

7. Družić Ljubotina, O. (2013). Siromaštvo kao izazov za socijalni rad u kontekstu ekonomske krize u Hrvatskoj. Ljetopis socijalnog rada, 20 (1), 183-200.

8. Družić Ljubotina, O. \& Kletečki Radović, M. (2011). Siromaštvo i socijalni rad: koliko je siromaštvo doista »tema« socijalnog rada? Ljetopis socijalnog rada, 18 (1), 5-29.

9. Družić Ljubotina, O., Sabolić, T. \& Kletečki Radović, M. (2017). Život obitelji s djecom u uvjetima siromaštva iz perspektive roditelja. Ljetopis socijalnog rada, 24 (2), 243-276, https://doi.org/10.3935/ljsr.v24i2.185.

10. Državni zavod za statistiku (2013). Pokazatelji siromaštva u 2011. konačni rezultati. Preuzeto s: http://www.dzs.hr/Hrv_Eng/publication/2012/14-01-03_01_2012.htm (17.12.2019.).

11. Državni zavod za statistiku (2017). Procjene stanovništva Republike Hrvatske u 2016. Preuzeto s: https://www.dzs.hr/Hrv_Eng/publication/2017/07-01-03_01_2017.htm(17.12.2019.).

12. Državni zavod za statistiku (2018). Pokazatelji siromaštva i socijalne isključenosti u 2017. Preuzeto s: https://www.dzs.hr/Hrv_Eng/publication/2018/14-01-01_01_2018.htm (2.5.2020.). 
13. Državni zavod za statistiku (2019). Pokazatelji siromaštva i socijalne isključenosti u 2018. Preuzeto s: https://www.dzs.hr/Hrv_Eng/publication/2019/14-01-01_01_2019.htm (2.5.2020.).

14. Državni zavod za statistiku (2018). Žene i muškarci u Hrvatskoj 2018. Preuzeto s: https://www.dzs.hr/Hrv_Eng/menandwomen/men_and_women_2018.pdf (6.9.2019.).

15. EMIN (2015). Toward adequate and accessible minimum income schemes in europe - Analysis of minimum income schemes and roadmaps in 30 countries participating in the EMIN project. Synthesis report. Preuzeto s: https://eminnetwork.files.wordpress.com/2013/04/emin-synthesisreport-road-map-2014-en.pdf (6.9.2019.).

16. EMIN (2017). EMIN context report developments in relation to minimum income schemes in Europe. Preuzeto s: https://eminnetwork.files.wordpress.com/2017/10/emin2-eu-context-report-2017-final.pdf (16.9.2019.).

17. Europska komisija (2015). Minimum income schemes in Europe: A study of national policies 2015. Preuzeto s: http://ec.europa.eu/social/main. jsp?langld=en\&catld=89\&newsld=2506\&furtherNews=yes (16.9.2019.).

18. Europski parlament (2017). Minimum Income Policies in EU Member States. Preuzeto s: http://www.europarl.europa.eu/RegData/etudes/ STUD/2017/595365/IPOL_STU(2017)595365_EN.pdf (16.9.2019.).

19. Hansen, H. C. \& Natland, S. (2016). The working relationship between social worker and service user in an activation policy context. Nordic Social Work Research, 7 (2), 101-114.

20. Hrvatska komora socijalnih radnika (2015). Etički kodeks socijalnih radnica i socijalnih radnika u djelatnosti socijalnog rada. Preuzeto s: https://www. hksr.hr/ (16.9.2019.).

21. Hrvatski zavod za zapošljavanje (2015). Mjesečni statistički bilten - 12 . Preuzeto s: http://www.hzz.hr/UserDocsImages/stat_bilten_12_2014.pdf (10.9.2019.).

22. Hrvatski zavod za zapošljavanje (2016). Mjesečni statistički bilten - 12. Preuzeto s: http://www.hzz.hr/UserDocsImages/stat_bilten_12_2015.pdf (10.9.2019.).

23. Hrvatski zavod za zapošljavanje (2017). Mjesečni statistički bilten - 12 . Preuzeto s: http://www.hzz.hr/UserDocsImages/stat_bilten_12_2016.pdf (10.9.2019.).

24. Hrvatski zavod za zapošljavanje (2018). Mjesečni statistički bilten - 12 . Preuzeto s: http://www.hzz.hr/UserDocsImages/stat_bilten_12_2017.pdf (10.9.2019.). 
25. Hrvatski zavod za zapošljavanje (2018). Registrirana nezaposlenost. Preuzeto s: http://statistika.hzz.hr/statistika.aspx?tiplzvjestaja=1 (10.9.2019.).

26. Ilijaš, A. \& Podobnik, M. (2018). Nestabilnost zakona o socijalnoj skrbi kako utječe na rad socijalnih radnika u centrima za socijalnu skrb? Ljetopis socijalnog rada, 25 (3), 427-450, https://doi.org/10.3935/ljsr.v25i3.242.

27. Kletečki Radović, M., Vejmelka, L. \& Družić Ljubotina, O. (2017). Učinak siromaštva na dobrobit i kvalitetu života obitelji iz perspektive djece. Ljetopis socijalnog rada, 24 (2), 199-242, https://doi.org/10.3935/ljsr. v24i2.181.

28. Knežević, B., Marić, I. \& Šućur, Z. (2017). Međusektorska suradnja u području distribucije hrane kao odgovor na probleme siromaštva i materijalne deprivacije. Revija za socijalnu politiku, 24 (2), 143-167, https://doi. org/10.3935/rsp.v24i2.1410.

29. Ministarstvo socijalne politike i mladih (2010). Godišnje statističko izvješće o primijenjenim pravima socijalne skrbi, pravnoj zaštiti djece, mladeži, braka, obitelji i osoba lišenih poslovne sposobnosti, te zaštiti tjelesno ili mentalno oštećenih osoba u Republici Hrvatskoj u 2009. godini. Preuzeto s: https://mdomsp.gov.hr/pristup-informacijama/statisticka-izvjesca-1765/ godisnje-izvjesce-2009/542 (2.9.2019.).

30. Ministarstvo socijalne politike i mladih (2011). Godišnje statističko izvješće o primijenjenim pravima socijalne skrbi u 2010. godini. Preuzeto s: https:// mdomsp.gov.hr/pristup-informacijama/statisticka-izvjesca-1765/statisticka-izvjesca-za-2010-godinu/2332 (2.9.2019.).

31. Ministarstvo socijalne politike i mladih (2012). Godišnje statističko izvješće o primijenjenim pravima socijalne skrbi u 2011. godini. Preuzeto s: https:// mdomsp.gov.hr/pristup-informacijama/statisticka-izvjesca-1765/statisticka-izvjesca-za-2011-godinu/2331 (2.09.2019.).

32. Ministarstvo socijalne politike i mladih (2013). Godišnje statističko izvješće o primijenjenim pravima socijalne skrbi u 2012. godini. Preuzeto s: https:// mdomsp.gov.hr/pristup-informacijama/statisticka-izvjesca-1765/statisticka-izvjesca-za-2012-godinu/2326 (2.09.2019.).

33. Ministarstvo socijalne politike i mladih (2014). Godišnje statističko izvješće o primijenjenim pravima socijalne skrbi u 2013. godini. Preuzeto s: https:// mdomsp.gov.hr/pristup-informacijama/statisticka-izvjesca-1765/statisticka-izvjesca-za-2103-godinu/2325 (2.9.2019.).

34. Ministarstvo socijalne politike i mladih (2015). Godišnje statističko izvješće o primijenjenim pravima socijalne skrbi u 2014. godini. Preuzeto s: https:// mdomsp.gov.hr/pristup-informacijama/statisticka-izvjesca-1765/statisticka-izvjesca-za-2014-godinu/2292 (2.9.2019.). 
35. Ministarstvo socijalne politike i mladih (2016). Godišnje statističko izvješće o primijenjenim pravima socijalne skrbi u 2015. godini. Preuzeto s: https:// mdomsp.gov.hr/pristup-informacijama/statisticka-izvjesca-1765/statisticka-izvjesca-za-2015-godinu/2291 (2.9.2019.).

36. Ministarstvo za demografiju, obitelj, mlade i socijalnu politiku (2017). Godišnje statističko izvješće o korisnicima i primijenjenim pravima socijalne skrbi u Republici Hrvatskoj u 2016. godini. Preuzeto s: https://mdomsp. gov.hr/pristup-informacijama/statisticka-izvjesca-1765/statisticka-izvjesca-za-2016-godinu/2290 (2.9.2019.).

37. Ministarstvo za demografiju, obitelj, mlade i socijalnu politiku (2018). Mjesečno statističko izvješće, prosinac 2017. Preuzeto s: https://mdomsp. gov.hr/pristup-informacijama/statisticka-izvjesca-1765/statisticka-izvjesca-za-2017-godinu/4505 (2.9.2019.).

38. Ministarstvo za demografiju, obitelj, mlade i socijalnu politiku (2018). Mjesečno statističko izvješće, ožujak 2018. Preuzeto s: https://mdomsp. gov.hr/pristup-informacijama/statisticka-izvjesca-1765/statisticka-izvjesca-za-2018-godinu/10185 (2.9.2019.)

39. Ministarstvo za demografiju, obitelj, mlade i socijalnu politiku (2019). Godišnje statističko izvješće o primijenjenim pravima socijalne skrbi, pravnoj zaštiti djece, mladih, braka, obitelji i osoba lišenih poslovne sposobnosti, te zaštiti tjelesno ili mentalno oštećenih osoba u Republici Hrvatskoj u 2018. godini. Preuzeto s: https://mdomsp.gov.hr/pristup-informacijama/statisticka-izvjesca-1765/statisticka-izvjesca-za-2018-godinu/10185 (2.5.2020.).

40. Odluka o osnovici za ostvarivanje prava po osnovi socijalne skrbi (1998). Narodne novine, 5/1998.

41. Odluka o osnovici za ostvarivanje prava po osnovi socijalne skrbi (2001). Narodne novine, 21/2001.

42. Odluka o osnovici za ostvarivanje prava po osnovi socijalne skrbi (2008). Narodne novine, 30/2008.

43. Operativni programi učinkoviti ljudski potencijali 2014. - 2020. (2014). Preuzeto s: https://strukturnifondovi.hr/wp-content/uploads/2017/03/ OPULJP_hr.pdf (6.9.2019.).

44. Puljiz, V., Kerovec, N., Žganec, N., Bežovan, G., Teodorović, B., Šućur, Z., Zovko, G. \& Zrinščak, S. (2001). Pravci budućeg razvitka sustava socijalne pomoći i socijalne skrbi Republike Hrvatske. Revija za socijalnu politiku, 8 (3), 291-299.

45. Rubil, I., Stubbs, P. \& Zrinščak, S. (2018). Dječje siromaštvo i strategije nošenja sa siromaštvom kućanstava u Hrvatskoj: kvantitativno-kvalitativna 
studija. Privredna kretanja i ekonomska politika, 26 (2), 59-116, https:// doi.org/10.15179/pkiep.26.2.2.

46. SPC (2015). Social Europe: Aiming for inclusive growth. Annual report of the Social Protection Committee on the social situation in the European Union. Preuzeto s: http://ec.europa.eu/social/main.jsp?catld=738\&langld=en\&publd=7744\&visible $=0$ (6.9.2019.).

47. Stubbs, P., Zrinščak S. (2015a.) ESPN thematic report on minimum income schemes. Croatia. Preuzeto s: http://ec.europa.eu/social/keyDocuments. jsp?pager.offset=30\&\&langld=en\&mode=advancedSubmit \&year=0\&country=0\&type=0\&advSearchKey=ESPNmis (11.10.2019.).

48. Stubbs, P., Ledić, M., Rubil, I. \& Zrinščak, S. (2017). Dječje siromaštvo i strategije nošenja sa siromaštvom kućanstava u Hrvatskoj. Policy brief. Zagreb: Ekonomski institut Zagreb.

49. Šućur, Z. (2001.) Siromaštvo: Teorije, koncepti i pokazatelji. Zagreb: Pravni fakultet Sveučilišta u Zagrebu.

50. Šućur, Z. (2005). Socijalna pomoć. U: Puljiz, V., Bežovan, G., Šućur, Z. \& Zrinščak, S. (ur.), Socijalna politika. Zagreb: Pravni fakultet.

51. Šućur, Z. (2008). Socijalna sigurnost i kvaliteta života starijih osoba bez mirovinskih primanja u Republici Hrvatskoj. Revija za socijalnu politiku, 15 (3), 435-454.

52. Šućur, Z. (2012). Stagnira li doista siromaštvo u Hrvatskoj? Društvena istraživanja: časopis za opća društvena pitanja, 21 (3), 607-629.

53. UNDP (2009). Mladi između obrazovanja i zapošljavanja: Isplati li se školovati? Zagreb: UNDP Hrvatska.

54. UNICEF (2015). Siromaštvo i dobrobit djece predškolske dobi u Republici Hrvatskoj. Ured UNICEF-a za Hrvatsku.

55. Ustav Republike Hrvatske. Narodne novine, 56/1990., 135/1997., 8/1998., 113/2000, 124/2000., 28/2001., 41/2001., 55/2001., 76/2010., 85/2010., 05/2014. - pročišćeni tekst.

56. Vuković, D. (2019). Modul 2: Uloga socijalnog mentora u provedbi socijalne aktivacije. Preuzeto s: https://bistra.si/images/2019/Dijana_Vukovic_-_Uloga_socijalnog_mentora_u_provedbi_socijalne_aktivacije.pdf (6.5.2020.).

57. Wolf, W. (2007). The European perspective on child poverty. Conference paper. Sofia: European Commission. DG Employment, Social Affairs and Equal Opportunities.

58. Zakon o socijalnoj skrbi. Narodne novine, 73/1997., 27/2001., 59/2001., 82/2001., 103/2003., 44/2006., 79/2007., 123/2010. - pročišćeni tekst. 
59. Zakon o socijalnoj skrbi. Narodne novine, 57/2011.

60. Zakon o socijalnoj skrbi. Narodne novine, 33/2012., 46/2013., 49/2013. pročišćeni tekst.

61. Zakon o socijalnoj skrbi. Narodne novine, 157/2013.

62. Zakon o socijalnoj skrbi. Narodne novine, 157/2013., 152/2014., 99/2015., 52/2016., 16/2017.a, 130/2017.b - pročišćeni tekst. 
Martina Podobnik

Croatian chamber of social workers

Antun Ilijaš

Social wellfare center Zagreb

Croatian chamber of social workers

\section{THE EFFICIENCY OF GENERAL SOCIAL ASSISTANCE BENEFITS AND THE ROLE OF SOCIAL WELFARE CENTERS IN COMBATING POVERTY}

\section{ABSTRACT}

The social work profession is rooted in combating poverty and the fight for human rights. Social welfare centers represent a key institution in that area, particularly the cash benefits departments in which social workers daily work with the poorest members of society. The system of social assistance benefits in Croatia includes the general and categorical social assistance programs. This paper is focused on general assistance programs, guaranteed minimum benefit and one-time allowance. The aforementioned rights are regulated by the Social Welfare Act which has been amended six times since 2011, thus bringing novelties to the area of realization of the right to general social assistance benefits. The paper presents the most important changes and provides an overview of their practical applicability. It also provides guidelines for improving efficiency of the two most important cash benefits with regard to the amount of the benefits and their targeting, efficiency with regard to beneficiary groups including children and retired persons and work activation of young persons (and) beneficiaries who are capable for work. Considering the crucial role of social workers in the deciding on the recognition of the right to benefits, special attention was paid to a critical overview the role of social workers $n$ the cash benefits departments.

Key words: guaranteed minimum benefit, poverty, social work, social welfare center.

\section{c) $(0)$}

Međunarodna licenca / International License:

Creative Commons Attribution-NonCommercial-NoDerivatives 4.0. 
